\title{
Effect of Bed Width and Hill Spacing on Yield and Quality of Sugar Beet under Newly Reclaimed Soils
}

\author{
Sahar F.T. Ghaly ${ }^{1}$, EL-Araby S.R. Salem ${ }^{2}$
}

\begin{abstract}
This work aims to investigate the effect of bed width and hill spacing on growth, productivity and quality traits of sugar beet. In order to achieve such a purpose two field experiments were conducted at two successive seasons (2012/2013 and 2013/2014) in Nubaria Research Station, EL-Behera Governorate, Egypt to study the effect of three bed width $(80,100$ and $120 \mathrm{~cm})$ and three hill spacing $(15,20$ and $25 \mathrm{~cm})$ on growth, yield and quality traits of sugar beet, (Kawamera variety).
\end{abstract}

The obtained results indicated that bed width and hill spacing had a significant effect on number of extractable roots/fed, root length and diameter, quality traits of sugar beet, (sucrose\%, sugar recovery\%, quality index, potassium, sodium and $\alpha-\mathrm{N}$ contents as mill equivalent/100 gm beet) and root and recoverable sugar yields /fed.

It can be concluded that, bed width $80 \mathrm{~cm}$ with hill spacing $20 \mathrm{~cm}$ achieved the highest values of root and recoverable sugar yields $(33.280$ and 4.699 ton/fed, respectively).

Sugar beet (Kawamera variety) grown in row ridges or beds systems gave the highest values of root length and diameter, root weight, sucrose $\%$ and quality index as well as root and recoverable sugar yields/fed. Such results may be due to decrease plant stand and in turn decreased the competition between sugar beet plants and availed more light, nutrients and water which encouraged the vegetative growth and consequently, resulted big roots, which may be with higher moisture content. These results reflect the negative correlation between root size and gross sugar content.

In addition, the results showed that, the impurities (K, $\mathrm{Na}$ and $\alpha$-amino $\mathrm{N}$ contents) decreased with increasing plant density (bed width and hill spacing).

Key wards: sugar beet, bed width, hill spacing, root yield, sugar content, recoverable sugar, $K, \mathrm{Na}$ and $\alpha$ amino $N$ contents and plant density.

\section{INTRODUCTION}

Sugar beet (Beta Vulgaris L.) has been introduced in Egypt as a second source for sugar production since 1981 to minimize the gap between the local production and the actual consumption.

Sugar produced from sugar beet increased from $7.36 \%$ in 1990 to $55 \%$ of the total local sugar production (2.298 million tons) in 2014 (CGSC, 2014).

Improvement of sucrose yield and potential root yield in sugar beet seemed to be a slow process and restricted because a negative correlation between sucrose concentration and root yield as well as needed to maintain an acceptable level of sucrose concentration.

Till now, studies are carrying out to find the proper technical recommendations for improving the productivity and quality of sugar beet under different conditions. Research on the extent to which the plant density influence the growth and formation of leaf area in particular development stages, especially those decisive for the yield and quality of sugar beet seed, has major scientific and production importance since it contributes a better seed utilization in final processing. It is though that number and distribution of plants per unit area, as well as appropriate fertilization are control problems in the technological production process of all field crops and especially in sugar beet seed production. Areas under seed sugar beet production are small in comparison with areas under other field crops. This is the main reason why there are very few professional or scientific studies from this area. Researches from North Africa (Campbell, 1968; Scott, 1968 and Longden, 1974) conducted with twice as many plants (300,000 plants/ha at harvest) as commonly recommended in other production regions.

Ismail and Allam (2007) showed that plant densities significantly affected root length and diameter, sodium $\%$ and sucrose $\%$ in the two seasons in addition to sugar yield in the $2^{\text {nd }}$ season. They added that sowing sugar beet at 28000 and 42000 plants/fed had given the highest yield of roots and sugar (ton/fed) and quality traits, respectively.

Nafei et al., (2010) used three plant densities 28000 ( $50 \mathrm{~cm}$ between rows $\times 30 \mathrm{~cm}$ between hills), 33000 (50 $\mathrm{cm}$ between rows $\times 25 \mathrm{~cm}$ between hills) and $42000(50 \mathrm{~cm}$ between rows $\times 20 \mathrm{~cm}$ between hills $)$. They reported that increasing plant population from 28000 to 42000 plants/fed caused a significant response in root length, diameter, fresh weight/plant, sucrose $\%$, total soluble solids, phosphorus $\%$ in roots

\footnotetext{
Department of treatments.

${ }^{2}$ Department of Physiology and Chemistry.

Sugar Crop Res. Inst, Agric. Res. Center, Giza, Egypt.

Received February 8, 2016, Accepted March 6, 2016
} 
beside tops, root and sugar yields (ton/fed) in the two seasons.

Refay (2010) investigated that root yield and quality traits of three sugar beet cultivars in relation to sowing date and stand densities. He showed that environmental variations due to planting date, plant population densities and varieties had an effect on yield and quality.

Shalaby et al., (2011) studied the relative performance of sugar beet varieties under three plant densities in newly reclaimed soils. They found that increasing plant spacing from 15 to $25 \mathrm{~cm}$ significantly increased root length and diameter, fresh weight, sucrose $\%$, root and sugar yields/fed. Impurities\%, i.e. (N, Na, and $\mathrm{K}$ ) were decreased significantly in the two seasons.

Plant density (bed width and hill spacing) and many other factors need to be taken into account for improving the productivity and quality of sugar beet.

Sugar beet grown in ridges or beds systems gave the highest values of root length and diameter, root weight, sucrose $\%$ and quality index as well as root and recoverable sugar yields/fed, (Abdou and Salim, 2008).

Smooth root sugar beet genotypes responded to plant density in different environments similarly to adapted standard root commercial cultivars. SR (sugar recovery\%) had enhanced when sugar beets were grown at the higher density of 71760 plants ha ${ }^{-1}$ (46 $\mathrm{cm}$ row width $\mathrm{x} 30 \mathrm{~cm}$ plant spacing), (Theurer and Saunders 1995; El-Sheref, 2007 and Ferweez et al., 2010).

Leilah et al., (2005) studied the effect of planting dates, plant population and nitrogen fertilization on sugar beet productivity under newly reclaimed sandy soils in Egypt and found that the highest root and sugar yields ha ${ }^{-1}$ were obtained with sowing sugar beet on both sides of ridges, $70 \mathrm{~cm}$ width and $25 \mathrm{~cm}$ between plants (114240 plants $\mathrm{ha}^{-1}$ ). Therefore, the increase of plant density was accompanied with a reduction in root and sugar yields/fed, (Taha, 1985; Kamel et al., 1989; EL-Khatib, 1991 and Ramadan, 1999). They also pointed out that sucrose $\%$ and sugar recovery $\%$ of beet roots were significantly increased with increasing plant density. In addition, they desired that the impurities ( $\mathrm{K}, \mathrm{Na}$ and $\alpha$-amino $\mathrm{N}$ contents) decreased with increasing plant density.

The present investigation was conducted in order to study the effect of bed width and hill spacing on productivity and quality traits of sugar beet under Nubaria conditions.

\section{MATERIALS AND METHODS}

Two field experiments were carried out during 2012/2013 and 2013/2014 seasons at Nubaria Research Station, EL-Behera Governorate to study the effect of plant densities in terms of the combinations between bed width and hill spacing on growth, productivity and quality traits of sugar beet. The present study included nine treatments which were the combination between three bed width and three hill spacing within the two sides of bed.

A split plot design with four replications was used. Three different distances of bed width, i.e. 80, 100 and $120 \mathrm{~cm}$ were arranged in the main plots. Meanwhile, three hills spacing within the two sides of beds $(15,20$ and $25 \mathrm{~cm}$ ) were allocated to the sub plots.

Sub-plots area was $48.0 \mathrm{~m}^{2}$ consisting of 12.0 meters wide and 4.0 meters long.

Sugar beet (Kawamera variety) used in this study was sowing dates were at 16 th and 18 th October in the tow seasons, respectively.

Nitrogen fertilizer was added at rate of $120 \mathrm{~kg}$ $\mathrm{N} /$ fed in two equal doses (the first was after the thinning, while the second added after 30 days later).

Phosphorus fertilizer was added at rate of $30 \mathrm{~kg}$ $\mathrm{P}_{2} \mathrm{O}_{5} /$ fed at planting, while potassium was added at rate of $24 \mathrm{~kg} \mathrm{~K}{ }_{2} \mathrm{O} /$ fed after thinning.

Soil of the experimental site has sandy texture. Physical and chemical properties of the experimental soils summarized in Table 1.

\section{Data recorded}

\section{A- Growth characteristics:}

At harvest (195 days from sowing) sample of 10 plants from each sub-plot was randomly taken to record root length and root diameter.

\section{B- Quality parameters:}

Twenty roots were taken randomly, send to the laboratory, cleaned with running tap water, dried, each sample was grated separately with grater into cassettes and mixed thoroughly to determine the quality characteristics as described by Cooke and Scott (1993).

Sucrose \% was estimated in fresh samples of sugar beet roots, using saccharometer according to the method described in AOAC (2005).

Alpha amino nitrogen, sodium and potassium contents: estimated according to the procedure of Sugar Company by Auto Analyzer as describe in AOAC (2005) the results calculated as mill equivalent/100 gm beet. 
Table 1. Physical and chemical properties of the experimental soils

\begin{tabular}{|c|c|c|c|c|c|c|c|c|c|c|c|c|}
\hline \multirow{2}{*}{ Seasons } & \multicolumn{3}{|c|}{ Partial size } & \multirow{2}{*}{$\begin{array}{c}\text { Soil } \\
\text { pH } \\
1: 2.5\end{array}$} & \multirow{2}{*}{$\begin{array}{c}\text { Soil } \\
\text { Textural }\end{array}$} & \multirow{2}{*}{$\begin{array}{l}\text { E.C. } \\
d s / m\end{array}$} & \multirow{2}{*}{$\begin{array}{r}\mathrm{CaCO}_{3} \\
\% \\
\end{array}$} & \multirow{2}{*}{$\begin{array}{c}\text { Organic } \\
\text { matter } \\
\%\end{array}$} & \multicolumn{4}{|c|}{ Available contents $\%$} \\
\hline & Clay & Silt & Sand & & & & & & $\mathbf{N}$ & $\mathbf{P}$ & & $\mathbf{K}$ \\
\hline $2012 / 2013$ & 3.0 & 3.3 & 93.7 & 7.7 & Sandy & 1.6 & $10.6 \%$ & 0.75 & 4.4 & 3.21 & & 132 \\
\hline $2013 / 2014$ & 3.6 & 4.7 & 91.7 & 7.8 & Sandy & 1.9 & $9.9 \%$ & 0.90 & 6.5 & 3.01 & & 120 \\
\hline \multirow[t]{2}{*}{ Seasons } & \multicolumn{4}{|c|}{ Soluble cautions (meq/l) } & \multicolumn{4}{|c|}{ Soluble anions (meq/l) } & \multicolumn{4}{|c|}{ Available contents (ppm) } \\
\hline & $\mathrm{Ca}^{++}$ & $\mathbf{M g}^{++}$ & $\mathrm{Na}^{+}$ & $\mathbf{K}^{+}$ & $\mathrm{CO}_{3-}$ & $\mathrm{HCO}_{-3}$ & $\mathrm{Cl}^{-}$ & $\mathrm{SO}_{-4}$ & B & $\mathbf{F e}$ & Zn & Mn \\
\hline $2012 / 2013$ & 2.00 & 3.02 & 3.24 & 0.25 & 2.50 & 1.10 & 3.02 & 2.17 & 0.31 & 4.2 & 2.6 & 3.8 \\
\hline $2013 / 2014$ & 2.05 & 3.00 & 3.14 & 0.35 & 2.60 & 1.09 & 3.00 & 2.10 & 0.35 & 4.1 & 3.5 & 2.4 \\
\hline
\end{tabular}

Sugar recovery\% was calculated using the equation of Cooke and Scott (1993).

Sugar recovery $\%=$ sucrose $\%-[0.29+0.343(\mathrm{~K}+$ $\mathrm{Na})+<\alpha-\mathrm{N}(0.094)]$, Where, $\mathrm{K}, \mathrm{Na}$ and $\alpha-\mathrm{N}$ determined as mill equivalent $/ 100 \mathrm{gm}$ beet.

Quality index was calculated as by Cooke and Scott (1993) using the following formula:

Quality index $\%=$ sugar recovery $\%$ x sucrose $\%$ x 100

\section{C- Productive traits:}

Number of extractable roots/fed at harvest (195 days from sowing) was counted.

Roots yield (ton /fed) after (195 days from sowing) plants of sugar beet from the inner beds of each subplot were harvested, topped and cleaned to determine roots yield as ton /fed on fresh weight basis.

Recoverable sugar yield (ton/fed) was calculated from the following equation:

Recoverable sugar yield $($ ton $/ \mathrm{fed})=$ roots yield (ton/fed) x sugar recovery $\%$.

The proper statistical analysis of all data was carried out according to lined by Gomez and Gomez

(1984). Homogeneity of variance was examined before combined analysis. Combined analysis was carried out. Differences among treatments were evaluated by the least significant difference test (LSD) at 0.05 level of probability.

\section{RESULTS AND DISCUSSIONS}

\section{A-Growth characters}

Data in Tables (2 and 3) revealed that, bed width had a significant effect on growth traits of sugar beet, i.e. root length and diameter at the two growing seasons and their combined.

From combined analysis, it could be noticed that increasing bed width from 80 to 100 and $120 \mathrm{~cm}$ led to increase root length by 6.65 and $12.83 \%$, while root diameter increased by 3.78 and $7.56 \%$, respectively .

Increasing bed width combined with increasing hill spacing led to decrease plant density of sugar beet and less competition for growth elements, such observations may reflect the increase of root length and diameter. These results are in a harmony with those reported by Kamel et al., (1989); Ramadan (1999) and Ferweez et al., (2010).

Table 2. Effect of bed width and hill spacing on root length $(\mathrm{cm})$ of sugar beet in the two seasons and their combined

\begin{tabular}{|c|c|c|c|c|c|c|c|c|c|c|c|c|}
\hline \multirow{3}{*}{$\begin{array}{l}\text { Bed } \\
\text { width } \\
(\mathrm{A})(\mathrm{cm})\end{array}$} & \multicolumn{4}{|c|}{$2012 / 2013$} & \multicolumn{4}{|c|}{$20113 / 2014$} & \multicolumn{4}{|c|}{ Combined } \\
\hline & \multicolumn{12}{|c|}{ Hill spacing(B)(cm) } \\
\hline & 15 & 20 & 25 & Mean & 15 & 20 & 25 & Mean & 15 & 20 & 25 & Mean \\
\hline 80 & 27.07 & 29.09 & 31.92 & 29.36 & 28.12 & 30.36 & 32.12 & 30.20 & 27.59 & 29.72 & 32.02 & 29.78 \\
\hline 100 & 29.39 & 31.26 & 32.19 & 30.95 & 30.18 & 32.30 & 34.27 & 32.25 & 29.78 & 31.78 & 33.73 & 31.76 \\
\hline 120 & 31.30 & 33.13 & 35.23 & 33.22 & 32.13 & 33.82 & 34.82 & 33.59 & 31.71 & 33.48 & 35.63 & 33.61 \\
\hline Mean & 29.25 & 31.16 & 33.11 & 31.17 & 30.14 & 32.16 & 33.74 & 32.01 & 29.69 & 31.66 & 33.79 & 31.72 \\
\hline F Value & $* *$ & $* *$ & $* *$ & & $* *$ & $* *$ & $* *$ & & $* *$ & $* *$ & $* *$ & \\
\hline \multicolumn{13}{|l|}{ LSD0.05 } \\
\hline $\mathrm{A}$ & \multicolumn{4}{|c|}{0.40} & \multicolumn{4}{|c|}{0.60} & \multicolumn{4}{|c|}{0.33} \\
\hline $\mathrm{B}$ & \multicolumn{4}{|c|}{0.47} & \multicolumn{4}{|c|}{0.32} & \multicolumn{4}{|c|}{0.27} \\
\hline $\mathrm{AB}$ & \multicolumn{4}{|c|}{ N.S } & \multicolumn{4}{|c|}{0.55} & \multicolumn{4}{|c|}{0.46} \\
\hline
\end{tabular}


Table 3. Effect of bed width and hill spacing on root diameter $(\mathrm{cm})$ of sugar beet in the two seasons and their combined

\begin{tabular}{|c|c|c|c|c|c|c|c|c|c|c|c|c|}
\hline \multirow{3}{*}{$\begin{array}{l}\text { Bed width } \\
\text { (A) }(\mathrm{cm})\end{array}$} & \multicolumn{4}{|c|}{$2012 / 2013$} & \multicolumn{4}{|c|}{$20113 / 2014$} & \multicolumn{4}{|c|}{ Combined } \\
\hline & \multicolumn{12}{|c|}{ Hill spacing(B) (cm) } \\
\hline & 15 & 20 & 25 & Mean & 15 & 20 & 25 & Mean & 15 & 20 & 25 & Mean \\
\hline 80 & 11.67 & 11.97 & 12.20 & 11.95 & 11.63 & 11.97 & 12.20 & 11.93 & 11.65 & 11.97 & 12.20 & 11.94 \\
\hline 100 & 12.02 & 12.30 & 12.50 & 12.27 & 12.30 & 12.37 & 12.67 & 12.45 & 12.16 & 12.33 & 12.58 & 12.36 \\
\hline 120 & 12.37 & 12.70 & 13.13 & 12.73 & 12.53 & 12.87 & 13.27 & 12.89 & 12.45 & 12.78 & 13.20 & 12.81 \\
\hline Mean & 12.02 & 12.32 & 12.61 & 12.32 & 12.15 & 12.40 & 12.71 & 12.42 & 12.09 & 12.36 & 12.66 & 12.37 \\
\hline F Value & $* *$ & $* *$ & $* *$ & & $* *$ & $* *$ & $* *$ & & $* *$ & $* *$ & $* *$ & \\
\hline \multicolumn{13}{|l|}{ LSD 0.05} \\
\hline A & \multicolumn{4}{|c|}{0.21} & \multicolumn{4}{|c|}{0.13} & \multicolumn{4}{|c|}{0.10} \\
\hline B & \multicolumn{4}{|c|}{0.17} & \multicolumn{4}{|c|}{0.15} & \multicolumn{4}{|c|}{0.11} \\
\hline $\mathrm{AB}$ & \multicolumn{4}{|c|}{0.11} & \multicolumn{4}{|c|}{0.35} & \multicolumn{4}{|c|}{0.33} \\
\hline
\end{tabular}

Concerning the hill spacing within the two sides of beds, it can be noticed from combined analysis in the following Tables that, hill spacing of sugar beet had a significant effect on the two studied growth traits of sugar beet, i.e. root length and diameter in the two growing seasons and combined.

Root length was proven to be longer under the narrowest bed width, which led to more elongation in the roots. These results may be due to different shares of utilized nutrients, water and other growth factors. The results are in agreement with those obtained by ElSheref (2007); Hilal (2010) and Ferweez et al., (2010).

Significant interactions were recorded between bed width and hill spacing with regard to root length $(\mathrm{cm})$ in the $2^{\text {nd }}$ season and their combined as shown in Tables $(2$ and 3 ). It could be noticed from combined analysis in the following tables that bed width at $120 \mathrm{~cm}$ and sowing seeds at $25 \mathrm{~cm}$ spacing contained the highest values of root length and diameter (35.63 and 13.20 $\mathrm{cm})$. On the other hand, the lowest values of root length and diameter $(27.59$ and $11.65 \mathrm{~cm})$ were scored for bed width $80 \mathrm{~cm}$ and seed spacing $15 \mathrm{~cm}$ of sugar beet.

\section{Table 4. Effect of bed width and hill spacing on sucrose\% of sugar beet in the two seasons} and their combined

\begin{tabular}{|c|c|c|c|c|c|c|c|c|c|c|c|c|}
\hline \multirow{3}{*}{$\begin{array}{l}\text { Bed } \\
\text { width (A) } \\
(\mathrm{cm})\end{array}$} & \multicolumn{4}{|c|}{$2012 / 2013$} & \multicolumn{4}{|c|}{$20113 / 2014$} & \multicolumn{4}{|c|}{ Combined } \\
\hline & \multicolumn{12}{|c|}{ Hill spacing(B) (cm) } \\
\hline & 15 & 20 & 25 & Mean & 15 & 20 & 25 & Mean & 15 & 20 & 25 & Mean \\
\hline 80 & 16.23 & 16.40 & 16.03 & 16.22 & 16.43 & 16.57 & 16.13 & 16.38 & 16.33 & 16.48 & 16.08 & 16.30 \\
\hline 100 & 15.10 & 15.90 & 14.93 & 15.31 & 15.17 & 15.93 & 15.03 & 15.38 & 15.13 & 15.92 & 14.98 & 15.34 \\
\hline 120 & 14.40 & 14.69 & 14.10 & 14.40 & 14.37 & 14.78 & 14.20 & 14.45 & 14.38 & 14.73 & 14.15 & 14.42 \\
\hline Mean & 15.24 & 15.66 & 15.02 & 15.31 & 15.32 & 15.76 & 15.12 & 15.40 & 15.28 & 15.71 & 15.07 & 15.35 \\
\hline F Value & $* *$ & $* *$ & $* *$ & & $* *$ & $* *$ & $* *$ & & $* *$ & $* *$ & $* *$ & \\
\hline \multicolumn{13}{|l|}{ LSD 0.05} \\
\hline A & \multicolumn{4}{|c|}{0.08} & \multicolumn{4}{|c|}{0.22} & \multicolumn{4}{|c|}{0.10} \\
\hline $\mathrm{B}$ & \multicolumn{4}{|c|}{0.06} & \multicolumn{4}{|c|}{0.11} & \multicolumn{4}{|c|}{0.08} \\
\hline $\mathrm{AB}$ & \multicolumn{4}{|c|}{0.10} & \multicolumn{4}{|c|}{0.18} & \multicolumn{4}{|c|}{0.10} \\
\hline
\end{tabular}

These results may be due to different shares of utilized nutrients, water and other growth factors. Such results confirmed the previously reported by Ramadan (1999); El- Sheref (2007); Hilal (2010) and Ferweez et al., (2010).

\section{B-Quality properties}

Results in this part of study (Tables 4 -9) clarified that there were significant differences among the studied bed width distances with respect to quality traits of sugar beet, i.e. sucrose $\%$, sugar recovery $\%$, quality index, potassium, sodium and $\alpha-\mathrm{N}$ content of sugar beet in the two growing seasons and combined. These results are in a harmony with those obtained by Abdou and Salim (2008) since they reported that the increase in root length and diameter may be due to less competition among plants and also for the same reasons of increasing ridge width allowed more solar radiation penetration among beet leaves and that caused more photosynthesis that increased sucrose content in root besides purity\%. Similar results were obtained by Hassanin (2001); Ahmed (2003) and El-Bakary (2006). 
Table 5. Effect of bed width and hill spacing on sugar recovery\% of sugar beet in the two seasons and their combined

\begin{tabular}{|c|c|c|c|c|c|c|c|c|c|c|c|c|}
\hline \multirow{3}{*}{$\begin{array}{l}\text { Bed } \\
\text { width } \\
(\mathrm{A})(\mathrm{cm})\end{array}$} & \multicolumn{4}{|c|}{$2012 / 2013$} & \multicolumn{4}{|c|}{$20113 / 2014$} & \multicolumn{4}{|c|}{ Combined } \\
\hline & \multicolumn{12}{|c|}{ Hill spacing(B)(cm) } \\
\hline & 15 & 20 & 25 & Mean & 15 & 20 & 25 & Mean & 15 & 20 & 25 & Mean \\
\hline 80 & 13.79 & 14.02 & 13.40 & 13.74 & 13.93 & 14.23 & 13.50 & 13.89 & 13.86 & 14.12 & 13.45 & 13.81 \\
\hline 100 & 12.38 & 13.34 & 12.09 & 12.60 & 12.49 & 13.40 & 12.28 & 12.72 & 12.43 & 13.37 & 12.19 & 12.66 \\
\hline 120 & 11.47 & 11.68 & 11.13 & 11.43 & 11.53 & 12.04 & 11.33 & 11.63 & 11.50 & 11.86 & 11.23 & 11.53 \\
\hline Mean & 12.55 & 13.01 & 12.21 & 12.59 & 12.65 & 13.22 & 12.37 & 12.75 & 12.60 & 13.12 & 12.29 & 12.67 \\
\hline F Value & $* *$ & $* *$ & $* *$ & & $* *$ & $* *$ & $* *$ & & $* *$ & $* *$ & $* *$ & \\
\hline \multicolumn{13}{|l|}{ LSD 0.05} \\
\hline $\mathrm{A}$ & \multicolumn{4}{|c|}{0.15} & \multicolumn{4}{|c|}{0.19} & \multicolumn{4}{|c|}{0.10} \\
\hline B & \multicolumn{4}{|c|}{0.11} & \multicolumn{4}{|c|}{0.12} & \multicolumn{4}{|c|}{0.08} \\
\hline $\mathrm{AB}$ & \multicolumn{4}{|c|}{0.19} & \multicolumn{4}{|c|}{0.21} & \multicolumn{4}{|c|}{0.13} \\
\hline
\end{tabular}

Table 6. Effect of bed width and hill spacing on quality index of sugar beet in the two seasons and their combined

\begin{tabular}{|c|c|c|c|c|c|c|c|c|c|c|c|c|}
\hline \multirow{3}{*}{$\begin{array}{l}\text { Bed } \\
\text { width } \\
\text { (A) }(\mathrm{cm})\end{array}$} & \multicolumn{4}{|c|}{$2012 / 2013$} & \multicolumn{4}{|c|}{$20113 / 2014$} & \multicolumn{4}{|c|}{ Combined } \\
\hline & \multicolumn{12}{|c|}{ Hill spacing(B) (cm) } \\
\hline & 15 & 20 & 25 & Mean & 15 & 20 & 25 & Mean & 15 & 20 & 25 & Mean \\
\hline 80 & 85.46 & 84.83 & 83.56 & 84.62 & 85.89 & 84.76 & 83.67 & 84.77 & 85.86 & 84.79 & 83.61 & 84.75 \\
\hline 100 & 83.75 & 81.94 & 80.97 & 82.22 & 84.10 & 82.34 & 81.71 & 82.72 & 83.92 & 82.14 & 81.34 & 82.47 \\
\hline 120 & 80.72 & 79.53 & 78.91 & 79.72 & 81.50 & 80.27 & 79.80 & 80.52 & 81.11 & 79.90 & 79.36 & 80.12 \\
\hline Mean & 83.31 & 82.10 & 81.15 & 82.19 & 83.83 & 82.46 & 81.73 & 82.67 & 83.63 & 82.28 & 81.44 & 82.45 \\
\hline F Value & $* *$ & $* *$ & $* *$ & & $* *$ & $* *$ & $* *$ & & $* *$ & $* *$ & $* *$ & \\
\hline \multicolumn{13}{|l|}{ LSD 0.05} \\
\hline $\mathrm{A}$ & \multicolumn{4}{|c|}{0.35} & \multicolumn{4}{|c|}{0.14} & \multicolumn{4}{|c|}{0.16} \\
\hline B & \multicolumn{4}{|c|}{0.37} & \multicolumn{4}{|c|}{0.38} & \multicolumn{4}{|c|}{0.25} \\
\hline $\mathrm{AB}$ & \multicolumn{4}{|c|}{0.09} & \multicolumn{4}{|c|}{0.10} & \multicolumn{4}{|c|}{0.08} \\
\hline
\end{tabular}

Table 7. Effect of bed width and hill spacing on potassium content * of sugar beet in the two seasons and their combined

\begin{tabular}{|c|c|c|c|c|c|c|c|c|c|c|c|c|}
\hline \multirow{3}{*}{$\begin{array}{l}\text { Bed } \\
\text { width } \\
(\text { A) }(\mathrm{cm})\end{array}$} & \multicolumn{4}{|c|}{$2012 / 2013$} & \multicolumn{4}{|c|}{$20113 / 2014$} & \multicolumn{4}{|c|}{ Combined } \\
\hline & \multicolumn{12}{|c|}{ Hill spacing(B) (cm) } \\
\hline & 15 & 20 & 25 & Mean & 15 & 20 & 25 & Mean & 15 & 20 & 25 & Mean \\
\hline 80 & 2.73 & 3.00 & 3.30 & 3.01 & 2.83 & 3.03 & 3.33 & 3.06 & 2.78 & 3.02 & 3.32 & 3.04 \\
\hline 100 & 3.17 & 3.57 & 3.77 & 3.50 & 3.10 & 3.47 & 3.63 & 3.40 & 3.13 & 3.52 & 3.70 & 3.45 \\
\hline 120 & 3.77 & 3.90 & 4.00 & 3.89 & 3.57 & 3.77 & 3.77 & 3.70 & 3.67 & 3.83 & 3.88 & 3.79 \\
\hline Mean & 3.22 & 3.49 & 3.69 & 3.47 & 3.17 & 3.42 & 3.58 & 3.39 & 3.19 & 3.46 & 3.63 & 3.43 \\
\hline F Value & $* *$ & $* *$ & $* *$ & & $* *$ & $* *$ & $* *$ & & $* *$ & $* *$ & $* *$ & \\
\hline \multicolumn{13}{|l|}{ LSD 0.05} \\
\hline $\mathrm{A}$ & \multicolumn{4}{|c|}{0.15} & \multicolumn{4}{|c|}{0.09} & \multicolumn{4}{|c|}{0.02} \\
\hline $\mathrm{B}$ & \multicolumn{4}{|c|}{0.11} & \multicolumn{4}{|c|}{0.11} & \multicolumn{4}{|c|}{0.07} \\
\hline $\mathrm{AB}$ & \multicolumn{4}{|c|}{0.07} & \multicolumn{4}{|c|}{0.08} & \multicolumn{4}{|c|}{0.13} \\
\hline
\end{tabular}

\footnotetext{
*= Potassium content as mill equivalents $/ 100$ gm beet.
} 
Table 8. Effect of bed width and hill spacing on sodium content * of sugar beet in the two seasons and their combined

\begin{tabular}{|c|c|c|c|c|c|c|c|c|c|c|c|c|}
\hline \multirow{3}{*}{$\begin{array}{l}\text { Bed } \\
\text { width } \\
(\mathrm{A})(\mathrm{cm})\end{array}$} & \multicolumn{4}{|c|}{$2012 / 2013$} & \multicolumn{4}{|c|}{$20113 / 2014$} & \multicolumn{4}{|c|}{ Combined } \\
\hline & \multicolumn{12}{|c|}{ Hill spacing(B)(cm) } \\
\hline & 15 & 20 & 25 & Mean & 15 & 20 & 25 & Mean & 15 & 20 & 25 & Mean \\
\hline 80 & 1.52 & 1.62 & 1.67 & 1.60 & 1.31 & 1.57 & 1.64 & 1.51 & 1.42 & 1.60 & 1.65 & 1.56 \\
\hline 100 & 1.92 & 1.66 & 1.79 & 1.79 & 1.58 & 1.63 & 1.66 & 1.62 & 1.59 & 1.65 & 1.73 & 1.66 \\
\hline 120 & 1.76 & 1.90 & 1.93 & 1.86 & 1.68 & 1.77 & 1.87 & 1.77 & 1.72 & 1.83 & 1.90 & 1.82 \\
\hline Mean & 1.73 & 1.73 & 1.80 & 1.75 & 1.52 & 1.66 & 1.72 & 1.63 & 1.58 & 1.69 & 1.76 & 1.68 \\
\hline F Value & $*$ & $*$ & $*$ & & $*$ & $*$ & $*$ & & $*$ & $*$ & $*$ & \\
\hline
\end{tabular}

LSD

0.05

\begin{tabular}{llll}
\hline $\mathrm{A}$ & 0.15 & 0.12 & 0.08 \\
\hline $\mathrm{B}$ & 0.06 & 0.15 & 0.07 \\
\hline $\mathrm{AB}$ & 0.11 & 0.09 & 0.11 \\
\hline
\end{tabular}

*= Sodium content as mill equivalents $/ 100$ gm beet.

Table 9. Effect of bed width and hill spacing on $\alpha$-amino nitrogen content of sugar beet in the two seasons and their combined

\begin{tabular}{|c|c|c|c|c|c|c|c|c|c|c|c|c|}
\hline \multirow{3}{*}{$\begin{array}{l}\text { Bed width } \\
\text { (A) (cm) }\end{array}$} & \multicolumn{4}{|c|}{ 2012/2013 } & \multicolumn{4}{|c|}{$20113 / 2014$} & \multicolumn{4}{|c|}{ Combined } \\
\hline & \multicolumn{12}{|c|}{ Hill spacing(B) (cm) } \\
\hline & 15 & 20 & 25 & Mean & 15 & 20 & 25 & Mean & 15 & 20 & 25 & Mean \\
\hline 80 & 1.81 & 1.86 & 1.88 & 1.85 & 1.72 & 1.82 & 1.86 & 1.80 & 1.77 & 1.84 & 1.87 & 1.83 \\
\hline 100 & 1.84 & 1.89 & 1.92 & 1.88 & 1.84 & 1.87 & 1.89 & 1.87 & 1.84 & 1.88 & 1.90 & 1.87 \\
\hline 120 & 1.93 & 1.95 & 1.95 & 1.94 & 1.92 & 1.93 & 1.93 & 1.93 & 1.93 & 1.94 & 1.94 & 1.94 \\
\hline Mean & 1.86 & 1.90 & 1.92 & 1.89 & 1.83 & 1.87 & 1.89 & 1.86 & 1.84 & 1.89 & 1.90 & 1.88 \\
\hline F Value & N.S & N.S & N.S & & $*$ & $*$ & N.S & & $*$ & $*$ & N.S & \\
\hline \multicolumn{13}{|l|}{ LSD 0.05} \\
\hline A & \multicolumn{4}{|c|}{0.06} & \multicolumn{4}{|c|}{0.04} & \multicolumn{4}{|c|}{0.03} \\
\hline B & \multicolumn{4}{|c|}{0.04} & \multicolumn{4}{|c|}{0.03} & \multicolumn{4}{|c|}{0.02} \\
\hline $\mathrm{AB}$ & \multicolumn{4}{|c|}{ N.S } & \multicolumn{4}{|c|}{0.04} & \multicolumn{4}{|c|}{0.04} \\
\hline
\end{tabular}

*= $\alpha$ - amino nitrogen as mill equivalents / $100 \mathrm{gm}$ beet

It could be noticed from combined analysis that increasing bed width distance from 80 to 100 and 120 $\mathrm{cm}$ led to decrease sucrose $\%$ by 5.38 and $11.53 \%$, sugar recovery\% by 8.33 and $16.51 \%$ as well as quality index by 2.69 and $5.46 \%$, while $\mathrm{K}$ content of beet root increased by 13.49 and $24.67 \%$, Na content of beet root increased by 7.1 and $17.42 \%$, as well as $\alpha-\mathrm{N}$ content of beet root increased by 2.19 and $6.01 \%$, respectively.

These results may be explained as follows, increasing bed width led to increase root volume and consequently, increased the root juice impurities, which reduced sucrose $\%$, sugar recovery $\%$ and quality index of sugar beet. Rice (1999) reported that the low plants counts had a significant effect on sucrose $\%$ and sugar recovery $\%$ of sugar beet. The present results are in the same line with those reported by Kamel et al., (1989); Ramadan (1999); Awad (2000) and Ferweez et al., (2010) since they showed that sucrose $\%$, sugar recovery $\%$ and quality index significantly increased with decreasing bed width of sugar beet in both seasons.
With regard to hill spacing within the two sides of beds, the data given in Tables (4 -9) revealed that seeds spacing exhibited a significant effect on the quality traits of sugar beet, i.e. sucrose $\%$, sugar recovery $\%$, quality index, potassium and sodium content of sugar beet in the two growing seasons and combined, except $\alpha$ - amino nitrogen in the first season.

It could be noted from combined analysis that increasing hill spacing of sugar beet from 15 to $20 \mathrm{~cm}$ led to increase sucrose $\%$ and sugar recovery $\%$ by 2.81 and $4.13 \%$, respectively. While, increasing hill spacing from 20 to $25 \mathrm{~cm}$ caused decreases in sucrose $\%$ and sugar recovery $\%$ by 1.37 and $2.46 \%$, respectively.

On the other hand, increasing hill spacing of sugar beet from 15 to 20 and $25 \mathrm{~cm}$ led to decrease quality index by 1.54 and $2.55 \%$, while increasing $\mathrm{K}$ content of sugar beet by 8.46 and $13.79 \%$, Na content by 6.96 and $11.39 \%$ and $\alpha$-amino $\mathrm{N}$ content by 2.72 and $3.26 \%$, respectively. 
These results may be explained as increasing hill spacing led to increase of root volume and consequently, reduced sucrose $\%$, sugar recovery $\%$, quality index of sugar beet as well as increased the impurities of root juice. These findings are in agreement with those obtained by Awad (2000); ElSheref (2007); Hilal (2010) and Ferweez et al., (2010).

The interaction between bed width and hill spacing was significant for sucrose $\%$ and sugar recovery $\%$ in the two growing seasons and combined as shown in Table (4).

The results revealed that applying bed width at 80 $\mathrm{cm}$ and hill spacing at $15 \mathrm{~cm}$ gave the highest values of sucrose \% (16.33), but the highest value of sugar recovery\% (14.12) was produced from the combined of bed width at $80 \mathrm{~cm}$ and hill spacing at $20 \mathrm{~cm}$ of sugar beet.

Largest spacing in both within and between beds produced largest beets than closer spacing consequently, the lowest quality of beet roots.

\section{C- Productive traits}

The results in Tables (10-12) indicated that bed width exhibited a significant effect on productive traits of sugar beet, i.e. number of extractable roots/fed, root and recoverable sugar yields (ton/fed) in the two growing seasons and combined.

From combined analysis it could be observed that increasing bed width from 80 to 100 and $120 \mathrm{~cm}$ led to decrease number of actual roots/fed at harvest by 17.02 and $30.96 \%$, root yield (ton/fed) of sugar beet by 9.41 and $19.50 \%$ and recoverable sugar yield by 16.76 and $32.73 \%$, respectively.

These results may be due to the decrease in both number of roots/fed at harvest and sucrose $\%$ of sugar beet with increasing the bed width from 80 to 100 and $120 \mathrm{~cm}$ (Tables 2-5). Rice (1999) reported that the low plant counts had a significant effect on root and recoverable sugar yields of sugar beet.

Stebbing et al., (2000) found that sugar beet root yield decreased by $18 \%$ when row width increased from 56 to $76 \mathrm{~cm}$ and by $25 \%$ when row spacing increased from 46 to $76 \mathrm{~cm}$. These findings are in harmony with those scored by Lauer (1995); Ramadan (1999) and Ferweez et al., (2010).

Regarding hill spacing within the two sides of beds, the data given in the previous tables revealed that hill spacing exhibited a significant effect on productive traits of sugar beet, i.e. number of actual roots/fed, root and recoverable sugar yields (ton/fed) in the two growing seasons and combined.

From combined analysis it could be noticed that, increasing seed spacing from 15 to 20 and $25 \mathrm{~cm}$ led to decrease number of actual roots/fed at harvest by 18.63 and $32.34 \%$ consequently, increasing seed spacing from 20 to $25 \mathrm{~cm}$ led to decrease root yield (ton/fed) of sugar beet by $5.92 \%$ and recoverable sugar yield (ton/fed) of sugar beet by $8.14 \%$, although increasing seed spacing from 15 to $20 \mathrm{~cm}$ led to increase root yield (ton/fed) of sugar beet and recoverable sugar yield (ton/fed) of sugar beet by 13.03 and $17.41 \%$, respectively.

Traditional recommendation of plant density in Egypt have been about 30,000-40,000 plants/fed. Stebbing et al., (2000) revealed that when the distance between plants increased, intra-plant competition became less. These findings are in the same trend with those obtained by El-Sheref (2007); Hilal (2010) and Ferweez et al., (2010).

The interactions of bed width and hill spacing (AB) were significant for number of actual roots/fed, root and recoverable sugar yields of sugar beet in the two growing seasons and combined, as shown in Tables $(10-12)$.

Table 10. Effect of bed width and hill spacing on number of roots of sugar beet in the two seasons and their combined

\begin{tabular}{|c|c|c|c|c|c|c|c|c|c|c|c|c|}
\hline \multirow{3}{*}{$\begin{array}{l}\text { Bed } \\
\text { width } \\
(\mathbf{A})(\mathrm{cm})\end{array}$} & \multicolumn{4}{|c|}{$2012 / 2013$} & \multicolumn{4}{|c|}{ 20113/2014 } & \multicolumn{4}{|c|}{ Combined } \\
\hline & \multicolumn{12}{|c|}{ Hill spacing(B)(cm) } \\
\hline & 15 & 20 & 25 & Mean & 15 & 20 & 25 & Mean & 15 & 20 & 25 & Mean \\
\hline 80 & 37570 & 30400 & 26470 & 31480 & 37400 & 29570 & 26970 & 31310 & 37980 & 29980 & 26720 & 31560 \\
\hline 100 & 32030 & 26130 & 19230 & 25800 & 32970 & 26770 & 20000 & 26580 & 32500 & 26450 & 19620 & 26190 \\
\hline 120 & 27300 & 21270 & 18170 & 22250 & 27400 & 21830 & 18800 & 22680 & 25350 & 21550 & 18480 & 21790 \\
\hline Mean & 32300 & 25930 & 21290 & 26510 & 32590 & 26060 & 21920 & 26860 & 31940 & 25990 & 21610 & 26510 \\
\hline F Value & $* *$ & $* *$ & $* *$ & & $* *$ & $* *$ & $* *$ & & $* *$ & $* *$ & $* *$ & \\
\hline \multicolumn{13}{|l|}{ LSD 0.05} \\
\hline $\mathrm{A}$ & \multicolumn{4}{|c|}{0.5} & \multicolumn{4}{|c|}{1.06} & \multicolumn{4}{|c|}{0.4} \\
\hline $\mathrm{B}$ & \multicolumn{4}{|c|}{0.77} & \multicolumn{4}{|c|}{0.23} & \multicolumn{4}{|c|}{0.38} \\
\hline $\mathrm{AB}$ & \multicolumn{4}{|c|}{1.33} & \multicolumn{4}{|c|}{0.39} & \multicolumn{4}{|c|}{0.66} \\
\hline
\end{tabular}


Table 11. Effect of bed width and hill spacing on sugar beet root yield (ton/fed) of sugar beet in the two seasons and their combined

\begin{tabular}{|c|c|c|c|c|c|c|c|c|c|c|c|c|}
\hline \multirow{3}{*}{$\begin{array}{l}\text { Bed width } \\
\text { (A) (cm) }\end{array}$} & \multicolumn{4}{|c|}{$2012 / 2013$} & \multicolumn{4}{|c|}{$20113 / 2014$} & \multicolumn{4}{|c|}{ Combined } \\
\hline & \multicolumn{12}{|c|}{ Hill spacing(B)(cm) } \\
\hline & 15 & 20 & 25 & Mean & 15 & 20 & 25 & Mean & 15 & 20 & 25 & Mean \\
\hline 80 & 30.84 & 32.81 & 27.80 & 30.48 & 30.71 & 33.74 & 31.58 & 32.01 & 30.77 & 33.28 & 29.04 & 31.03 \\
\hline 100 & 27.01 & 31.11 & 23.60 & 27.24 & 26.83 & 31.83 & 26.27 & 28.31 & 26.92 & 31.47 & 25.93 & 28.11 \\
\hline 120 & 24.12 & 27.91 & 21.97 & 24.67 & 24.60 & 28.33 & 22.70 & 25.21 & 24.48 & 28.12 & 22.33 & 24.98 \\
\hline Mean & 27.32 & 30.61 & 24.46 & 27.46 & 27.38 & 31.30 & 26.85 & 28.51 & 27.39 & 30.96 & 25.77 & 28.04 \\
\hline F Value & $* *$ & $* *$ & $* *$ & & $* *$ & $* *$ & $* *$ & & $* *$ & $* *$ & $* *$ & \\
\hline \multicolumn{13}{|l|}{ LSD 0.05} \\
\hline $\mathrm{A}$ & \multicolumn{4}{|c|}{1.59} & \multicolumn{4}{|c|}{0.46} & \multicolumn{4}{|c|}{0.60} \\
\hline $\mathrm{B}$ & \multicolumn{4}{|c|}{1.44} & \multicolumn{4}{|c|}{0.43} & \multicolumn{4}{|c|}{0.71} \\
\hline $\mathrm{AB}$ & \multicolumn{4}{|c|}{2.49} & \multicolumn{4}{|c|}{0.74} & \multicolumn{4}{|c|}{1.23} \\
\hline
\end{tabular}

Table 12. Effect of bed width and hill spacing on recoverable sugar yield (ton/fed) of sugar beet in the two seasons and their combined

\begin{tabular}{|c|c|c|c|c|c|c|c|c|c|c|c|c|}
\hline \multirow{3}{*}{$\begin{array}{l}\text { Bed } \\
\text { width } \\
\text { (A) }(\mathrm{cm})\end{array}$} & \multicolumn{4}{|c|}{$2012 / 2013$} & \multicolumn{4}{|c|}{ 20113/2014 } & \multicolumn{4}{|c|}{ Combined } \\
\hline & \multicolumn{12}{|c|}{ Hill spacing(B) (cm) } \\
\hline & 15 & 20 & 25 & Mean & 15 & 20 & 25 & Mean & 15 & 20 & 25 & Mean \\
\hline 80 & 4.253 & 4.600 & 3.725 & 4.193 & 4.278 & 4.801 & 4.263 & 4.447 & 4.265 & 4.699 & 3.906 & 4.290 \\
\hline 100 & 3.344 & 4.150 & 2.853 & 3.449 & 3.351 & 4.265 & 3.226 & 3.614 & 3.346 & 4.207 & 3.161 & 3.571 \\
\hline 120 & 2.766 & 3.260 & 2.445 & 2.824 & 2.836 & 3.411 & 2.572 & 2.940 & 2.815 & 3.335 & 2.508 & 2.886 \\
\hline Mean & 3.454 & 4.003 & 3.008 & 3.489 & 3.488 & 4.159 & 3.354 & 3.667 & 3.475 & 4.080 & 3.192 & 3.582 \\
\hline F Value & $* *$ & $* *$ & $* *$ & & $* *$ & $* *$ & $* *$ & & $* *$ & $* *$ & $* *$ & \\
\hline \multicolumn{13}{|l|}{ LSD 0.05} \\
\hline $\mathrm{A}$ & \multicolumn{4}{|c|}{0.21} & \multicolumn{4}{|c|}{0.46} & \multicolumn{4}{|c|}{0.10} \\
\hline $\mathrm{B}$ & \multicolumn{4}{|c|}{0.18} & \multicolumn{4}{|c|}{0.43} & \multicolumn{4}{|c|}{0.09} \\
\hline $\mathrm{AB}$ & \multicolumn{4}{|c|}{0.31} & \multicolumn{4}{|c|}{0.74} & \multicolumn{4}{|c|}{0.16} \\
\hline
\end{tabular}

It could be noticed from combined analysis that bed width at $80 \mathrm{~cm}$ and hill spacing at $20 \mathrm{~cm}$ achieved the highest values of root and recoverable sugar yields (33.28 and 4.699 tons/fed). While the lowest values of actual roots number/fed at harvest (18480 roots/fed), root and recoverable sugar yields (22.33 and 2.508 tons/fed) were scored with bed width at $120 \mathrm{~cm}$ and hill spacing at $25 \mathrm{~cm}$, respectively. Sugar beet root yield, sugar percentage, and purity were higher for sugar beet planted in $40 \mathrm{~cm}$ rows compared with sugar beet planted in $60 \mathrm{~cm}$ rows (O’Connor, 1983).

Narrower rows, such as $45 \mathrm{~cm}$ are more likely to produce large root yields and recoverable sugar because they help to compensate for poor plant establishment (Anonymous, 1995). Rice (1999) reported that there was a fall in root and sugar yields in the widest rows. Stebbing et al., (2000) showed that, row spacing of $40 \mathrm{~cm}$ in India, gave the highest yields of root and sugar, while that of 50 and $60 \mathrm{~cm}$ gave similar yields. Such data confirmed the previous reports of EL-Sheref (2007) and Hilal (2010).

\section{CONCLUSION}

From the previous data, it could be concluded that bed width at $80 \mathrm{~cm}$ and hill spacing at $20 \mathrm{~cm}$ was recommended under these conditions because it achieved the highest values of root and recoverable sugar yields (33.280 and 4.699 tons/fed, respectively) increasing income value of grower and sugar production for the factory, as well as water use efficiency and weed competition.

This is also helping in reducing the gap between sugar consumption and production at the national level. Therefore, it is recommended that to study bed width and hill spacing for different varieties to achieve the highest production.

\section{REFERENCES}

Abdou, M.A., and E.H.H. Salim. 2008. Effect of ridges width, hill spacing and nitrogen level on sugar beet productivity and quality. J. Agric \&Environ. Sci. Alex. Univ. 7(2): 12-26.

Ahmed, A.M.A. 2003. Effect of agricultural practices on productivity of some sugar beet varieties. Ph. D. Thesis, Fac. Agric. Suez Canal Univ. Egypt. 
Anonymous. 1995. In Sugar beet: A grower's guide. The Sugar Beet Res. and Extent. Commit. London.

AOAC. 2005. Association of Official Analytical Chemists. Official Methods of Analysis, $26^{\text {th }}$ Ed., AOAC Inter., Washing., D.C. USA.

Awad, N.M. 2000. A study on the performance of two sugar beet planters one of them manufactured and developed to suit small holdings.Ph .D. Thesis, Agric. Mech. Dept., Fac. of Agric., Eng. Kafr El- Sheikh, Tanta Univ.

Campbell, S.C. 1968. Sugar beet seed production on Oregon USA, report of the $31^{\text {st }}$ Congress of the Inter. Institute for Sugar Beet. Res. 165-174.

CCSC. 2014. Central Council for Sugar Crops. Annual Report, Ministry of Agric. Egypt. (In Arabic)

Cooke, D. A., and R. K. Scott. 1993. The Sugar Beet Crop. Science and Practice Published by Chapman \& Hall, London.

El-Bakary, H.M.Y. 2006. Studies on yield and quality characters of some sugar beet varieties. M. Sc. Thesis, Fac. Agric. Al-Azhar Univ.

EL-Khatib, H.S.Y. 1991. Effect of plant population and distribution and $\mathrm{N}, \mathrm{K}$ fertilization on growth, yield and quality of sugar beet (Beta Vulgaris L.) . M. Sc. Thesis, Fac. Agric. Mansoura Univ., Egypt.

EL-Sheref, E. EJVL. 2007. Effect of irrigation system and planting pattern on yield and quality of sugar beet under North Delta conditions. J. Agric. Mansoura Univ. 32(5):3269-3287.

Ferweez, H., Maha M. ELZeny, and A.M. Elwan. 2010. Effect of planting densities on productivity and quality of sugar beet (Beta Vulgaris L.) under Middle Egypt conditions .Minia J. of Agric. Res. And Develop. 30(3):363-376.

Gomez, K.A., and A.A. Gomez. 1984. Statistical Procedures for Agricultural Research, Second Edition. John Willey and Sons, New York, pp. 680.

Hassanin, M.A. 2001. Effect of hill spacing and potassium fertilization on sowing dates on sugar beet yield and quality. Bull. Fac. Agric. Cairo Univ. 52:27-46.

Hilal, S.M.M. 2010. Effect of some cultural treatments on yield and quality of sugar beet (Beta Vulgaris L.). M. Sc Thesis, Fac. Agric., Kafr El-Sheikh, Tanta Univ.

Ismail, A.M.A., and S.M. Allam. 2007. Yield and technology traits of sugar beet as affected by planting density, $\mathrm{P}$ and $\mathrm{K}$ fertilization. The $3^{\text {rd }}$ Conf. Sustain. Agric. Develop., Fac.Agric. Fayoum Univ. 12-14 November:15-28.
Kamel, M.S., E.A. Mahmoud, A.A. Abdel-Hafez, E.O. Abustait, and B.S. Hassanein. 1989. Effect of plant density, thinning time and. nitrogen fertilization on growth, yield and quality of sugar beet . Assiut J. Agric. Sci. 20(2):225-238.

Lauer, J.C. 1995. Plant density and nitrogen rate effects on sugar beet yield and quality early in harvest. Agro. J. 87:469-475.

Leilah, A.A., M.A. Badawy, E.M. Said, M.H. Ghonema, and M.A.E. Abdou.2005. Effect of planting dates, plant population and nitrogen fertilization on sugar beet productivity under newly reclaimed sandy soils in Egypt. Scientific J. of King Faisal (Basic and Applied Sciences) 6(1):95-110.

Longden, P.C. 1974. Harvesting sugar beet seed. J. Agric. Sci. Cambridge. 3:435-442.Nafei, A.I., A.M.H. Osman, and Maha, M. El-zeny. 2010. Effect of plant densities and potassium fertilization rates on yield and quality of sugar beet crop in sandy reclaimed soils. J. of Plant Production, Mansoura Univ. 1(2):229-237.

O'Connor, L. 1983. Influence of nitrogen fertilizer, plant density, row width and their interactions on sugar beet yield and quality. Irish J.Agric. Res. 22:189-202.

Ramadan, B.S.H. 1999. Differential response of some sugar beet varieties to plant density and harvesting dates. J. Agric. Sci. Mansoura Univ. 24(2):413-423.

Refay, Y.A. 2010. Root yield and quality traits of three sugar beet (Beeta Vulgaris L.) varieties in relation to sowing date and stand densities . World J. Agric. Sci. 6 (5):589594.

Rice, B. 1999. Plant populations and row widths for diploid sugar beet varieties. Teagase, 19 sandy mount Avenue, Dublin 4.

Scot, R.K. 1968. Sugar beet seed growing in Europe and North America. J. Int. Sugar Beet Res. 3: 53-84.

Shalaby, N.M.E., A.M.H. Osman, and A.H.S.A. ALLabbody. 2011. Relative performance of sugar beet varieties under three plant densities in newly reclaimed soils. Egypt J. Agric. Res. 89(1): 291-298.

Stebbing, J.A., R.G. Wilson, A.R. Martin, and J.A. Smith. 2000. Row spacing, redroot pigweed (Amaranthus retroflexus) density, and sugar beet (Beta Vulgaris L.) cultivar effects on sugar beet Develop. J. of Sugar Beet Res. 37(2):11-31.

Taha, E.M. 1985. Effect of different rates of nitrogen and plant spacing on growth, yield and quality of sugar beet. Minia J. Agric. Res. Rev. 7(3): 1017-1030.

Theurer, J.C., and J.W. Saunders. 1995. Row spacing and plant density effects on smooth root sugar beets. J. of Sugar Beet Res. 32(2\&3):69-78 


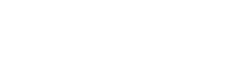

\section{تأثير عرض المصطبة والمسلفة بين الجور عل إنتاجية وجوة بنجر اللسكرف الارالف الجيسة}

سحرفايز توفيق غالى، العربسسالم رمضانسام

وقد أوضصت النتائج المتحصل عليها و وجود تأثير معنوى لعرض المصطبة والمسافة بين الجور على الصفلت

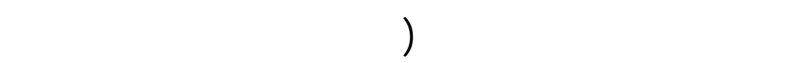

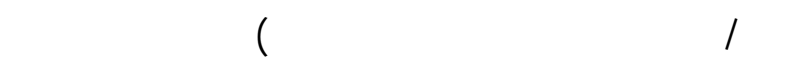
الجوة(نسبة السكروز، غسبة اللسكر القالب للمستخرج،

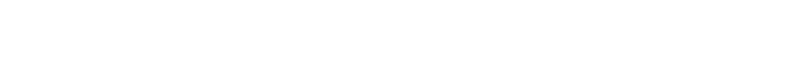

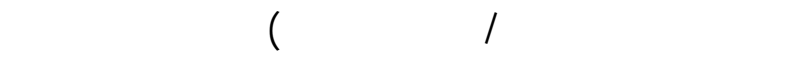
لجذور بنجر السكر (نانتج الجذور الظيفة وناتج اللسكر القالب للمستخراجطن/فدلن).

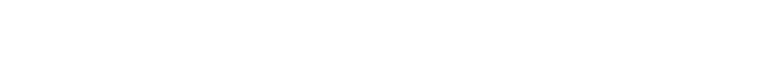

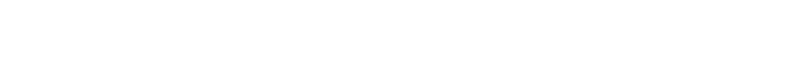

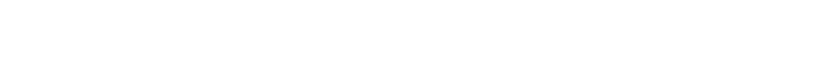

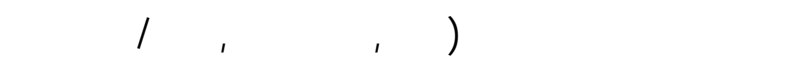

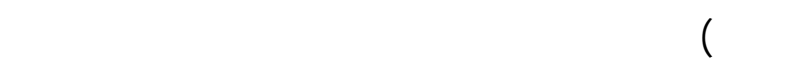

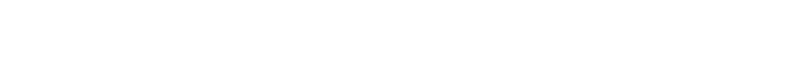
يساعد في تقلبل الفجوة بين إنتاج ولستهلاك للسكر على

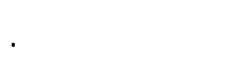

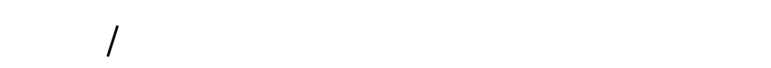

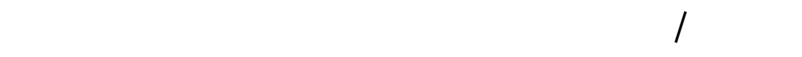

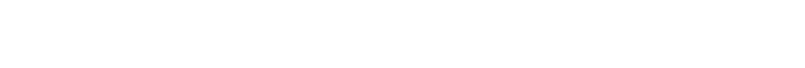
المصططب والمسلة بين الجور على إنتاجية وجولة بنجرر لمكر فى الاراض الجيية.

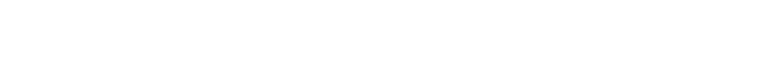
بنجر المكر عملية صعبة، بسب العلاقة العكسية بين تركيز للسكر وحهم ووزن الجذور وبين عدد الجذور الصالحة اللتصنع وتركيز للسكرفى الجذور. ولهذه الأسبب أقيمت هاتلان التجربتان لدربلسة تأثير

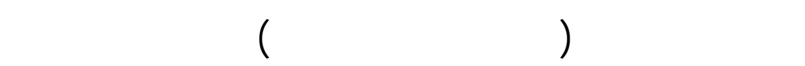

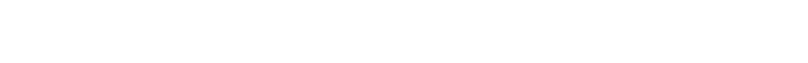

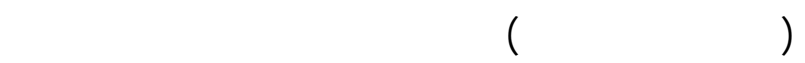

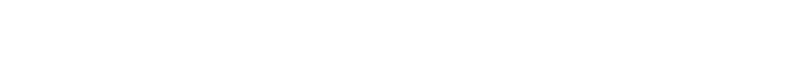
الجودة والصفات الانتلجية لبنجر اللسكر صف 